\title{
Drag kings - kamp czy zaangażowanie polityczne? Analiza zjawiska drag na przykładzie polskich drag kingów
}

Iwona Stasik

AGH w Krakowie

Niniejsza praca koncentruje się wokót tematyki występów drag kingowych. Autorka próbuje odpowiedzieć w niej na pytanie, czym jest występ drag kings - zabawa, kampem, czy może zaangażowaniem politycznym. W części pierwszej zarysowane zostały konteksty teoretyczne badanego zjawiska, a także przedstawiono wyniki dotychczasowych badań. Druga część artykułu zawiera prezentację wyników badań własnych. Badania prowadzone byty metoda etnograficzna, a użyte techniki to wywiad pogtębiony oraz analiza treści. Przeprowadzone zostały 4 wywiady z przedstawicielkami polskiej sceny drag kingowej, natomiast analizie treści zostały poddane nagrania 55 występów. Wyniki badań pozwalaja sadzić, że choć polityczność jest mocno osadzona w występach drag kingowych, to jednak nie jest to jedyna kategoria, jaka można owe występy opisać.

\section{Wstęp}

Podczas gdy męskość wciąż uznawana jest za normę niepotrzebującą głębszych analiz (MajkaRostek 2010: 10), drag kings biorą ją na celownik, bawiąc się jej znaczeniami. Przedstawiają nie tylko stereotypową, heteronormatywną męskość, ale wszystkie jej odcienie. W wątpliwość poddają także sztywny, binarny podział płci - pokazując, że nic nie jest tak oczywiste, jakim wydaje się być.

Jako fenomen, który obnaża kulturową konstrukcję płci, zjawisko drag jest istotnym elementem kultury queerowej. Drag queens, dzięki swojej obecności w kulturze popularnej, stały się w Polsce znane szerszej publiczności (a nie tylko uczestnikom kultury LGBTQ). Inaczej sprawy mają się w przypadku drag kings - znajomość tego zjawiska jest nikła, a występy niszowe.

Z wielu analiz wynika (Rupp, Taylor, Shapiro 2010; Kulpa 2002), że zjawisko analogiczne do występów drag kings - czyli występy drag queens - cechują się tym, iż są one przede wszystkim kampowe. Dotychczas opublikowane prace na temat drag kings często mówią o polityczności występów lub przynajmniej o ich politycznym potencjale (Rupp, Taylor, Shapiro 2010; Łojas, Dynarski 2010; DiFranco 2004), co może sugerować tezę, iż podobnie można odbierać występy 
polskich performerek drag. Należy też zastanowić się, czy możliwe jest połączenie polityczności z kampem, oraz czy możliwe są inne, nieodwołujące się do żadnej z tych kategorii, interpretacje występów.

Niniejsza praca podejmuje tematykę występów drag kings z perspektywy celów i motywacji performerek. W artykule chcę zastanowić się nad tym, do której z kategorii - kamp ${ }^{1}$, zabawa, zaangażowanie polityczne - można przyporządkować występy drag kings.

\section{Konteksty teoretyczne drag kings}

Etymologia słowa drag wywodzi się z języka angielskiego, gdzie wyrażenie „in drag" oznacza "W przebraniu osoby innej płci" (Świrek 2010: 148). Andrew Ross pisze, że drag to rola, która zostaje odgrywana dla publiczności, i dlatego należy ją odróżnić od transwestytyzmu i transseksualizmu (2012).

Judith Butler podkreśla, że drag jest potwierdzeniem tezy, iż płeć jest performatywnie tworzona. Choć może się wydawać, że drag jest subwersywny, to według Butler "nie ma oczywistego związku między drag i subwersją" (1993: 125). Mimo to filozofka wyraża pogląd, iż w spektaklu drag parodiowane jest pojęcie autentycznej, czy też pierwotnej, tożsamości płciowej (2012: 495).

Kim zatem jest drag king? Autorzy książki "Drag King. Anthology" wskazują na problemy definicyjne, jakie wiążą się z tym terminem. Zdefiniowanie drag kinga jako kobiety, która na scenie występuje jako mężczyzna, łączy się z kategoryzacją płci. Problem pojawia się, gdy dana osoba nie identyfikuje się z binarnym podziałem na kobiety i mężczyzn (Troka, LeBesco, Noble 2002). Dorota Majka-Rostek dzieli definicje drag kings na definicje wąskie oraz szerokie - te drugie, jej zdaniem, wydają się być odpowiedzią na problem wiążący się z kategoryzacją płci. Definicje wąskie mówią o tym, że drag kingiem jest kobieta, która na scenie występuje jako mężczyzna. Szerokie definicje podkreślają natomiast, iż drag kingiem może być każda osoba (bez względu na płeć), która robi przedstawienie z kulturowej męskości (2010: 7). Ciekawą definicję drag kings podają Leila J. Rupp, Verta Taylor i Eve Ilana Shapiro. Piszą one, że drag kings to: biologiczne kobiety odgrywające

\footnotetext{
${ }^{1}$ Kamp odróżniam od zabawy dlatego, iż jego ważnymi cechami są stylizacja i zamierzona nienaturalność. Pojęcie kampu szerzej wyjaśniam w dalszej części artykułu.
} 
męskość, osoby identyfikujące się jako transpłciowe odgrywające kobiecość lub męskość, a także osoby identyfikujące się jako kobiety odgrywające kobiecość (tak zwane bio queens) (2010: 276). Strategiami używanymi w trakcie występów dragowych są genderbending, genderfucking, genderblending czy też genderqueer. Genderbending to określenie używane w stosunku do osób, które przekraczają lub naginają swoją płeć kulturową. Inaczej rzecz ujmując, to androginiczne formy ekspresji oraz zachowywanie się w sposób charakterystyczny dla osób przeciwnej płci (Czapliński, Mizerka 2012: 690-691). Pojęciem podobnym do genderbendingu jest genderblending. Według Holly Devor jest to pojęcie definiujące osoby, których zachowanie i ubiór jest pomieszaniem męskości i kobiecości, choć przynależą one do określonej płci biologicznej oraz identyfikują się z odpowiadającą jej płcią społeczno-kulturową (1989). Genderfuck wydaje się być kategorią w większym stopniu polityczną niż genderbending. Genderfuck to "polityczna tożsamość płciowa, która powstała w trakcie przemian lat 50. i 60. XX w. U swoich podstaw ma zasadę, że prywatne jest polityczne" (Świrek 2010: 150). W występach drag strategii genderfuckingu można dopatrywać się w tworzeniu i przedstawianiu postaci niejednoznacznej płciowo - postaci androgynicznej, lekceważącej płeć kulturową (Marszałek 2010: 65).

\section{Kamp i jego (nie)polityczność}

O ile definiowanie zjawiska drag nie sprawia większych problemów, tak ze zdefiniowaniem kampu pojawiają się liczne trudności, ponieważ "kamp z definicji jest niedefiniowalny” (Adler 2008: 20). U podstaw kampu leży sztuczność i stylizacja - to kicz, który stawia formę wyżej niż treść (Malinowska 2008: 152). Jednak, podczas gdy kicz nie jest świadomy swojej kiczowatości, kamp zdaje sobie sprawę z tego, czym jest (Serafin 2008: 15). Całą istotę tego zjawiska można zawrzeć w zdaniu kończącym esej Susan Sontag: „Odpowiedź, która określa kamp: to jest dobre, bo jest okropne” (1979: 323).

Część teoretyczek i teoretyków zgadza się co do tego, że kamp jest zakorzeniony w kulturze LGBTQ, gdyż był on sygnałem skierowanym do osób homoseksualnych i przez nich odczytywanym (Zakrzewska 2005: 238-239). Przemysław Czapliński podkreśla, że kamp powstał jako przejaw tożsamości homoseksualnej, a na początku rozwijał się dzięki kulturze LGBTQ: „Ludycznie odgrywać heteroseksualne aspekty kultury dominującej z pozycji odmieńca i odmiennościowe aspekty kultury podporządkowanej z perspektywy dominującej - to właśnie znaczyło uprawiać kamp" (2012: 10). 
Warto zadać pytanie o to, czy kamp może być polityczny. Według Sontag wrażliwość kampu jest niezaangażowana (1979: 308). Jeśli jednak przyjąć tezę Butler o tym, że kamp może być subwersywny (2008), w pewnym sensie można zacząć mówić o jego polityczności. Podobne wnioski nasuwają się z widocznego połączenia kampu i kultury homoseksualnej. Kamp

z politycznego punktu widzenia jest postulatem społecznej widzialności odmieńców. Jeśli jest on aktywistyczną strategią, to jego polityczność jest, paradoksalnie, krytyką polityki jako sposobu sprawowania władzy i kontroli nad ciałem, płcią i tożsamością. Kamp jest polityczny, ale krytycznie. (Kaliściak 2008:134)

Z pewnością można stwierdzić tylko to, iż „nigdy nie jest pewne, czy kampowiec chce przyjemności, czy rewolucji" (Czapliński 2012: 11).

\section{Stan badań}

Istnieje wiele publikacji poświęconych występom drag queens (Taylor, Rupp 2004; Perkins 2002; Schacht, Underwood 2004; Berkovitz, Belgrave, Halberstein 2007), natomiast zdecydowanie mniej jest badań dotyczących zagadnień związanych z występami drag kings (Szkudlarek 2010; DiFranco 2004; Troka, LeBesco, Noble 2002). Być może jest to spowodowane tym, że kultura drag kings to fenomen, który na większą skalę pojawił się dopiero w latach 90. XX wieku, podczas gdy Esther Newton pisała o drag queens już w 1972 roku (Rupp, Taylor, Shapiro 2010: 276). Dodatkowo drag queens cieszą się większym zainteresowaniem badaczek i badaczy - zresztą tak jak ogół zagadnień dotyczących kobiecości - ponieważ męskość stanowi pewną oczywistość i uważa się, że nie wymaga ona większych analiz (Majka-Rostek 2010: 10). Obecnie zaobserwować można coraz większą popularność badań dotyczących męskości, jednak tematyka drag kings (przynajmniej na gruncie polskim) nie jest wciąż wystarczająco rozwinięta.

Analizując wypowiedzi polskich performerek drag king, można podzielić ich motywacje na dwie grupy: indywidualne oraz posiadające pewne elementy ideowe. Do pierwszej grupy zaliczyć można spełnienie marzeń o byciu aktorką, poczucie popularności, chęć walki ze swoją nieśmiałością i budowanie pewności siebie. Druga grupa motywacji to chęć wyjścia poza dychotomiczną kategoryzację płci oraz zakwestionowania tego, co wydaje się być oczywiste (Majka-Rostek 2010: 
11-13). Na polityczność występów może wskazywać także to, że drag kings często wywodzą się ze środowiska osób nieheteroseksualnych. Jeżeli potraktować występ drag kinga jako zabawę z płcią i jeżeli występująca kobieta także jest lesbijką - to pojawiają się kolejne znaczenia. Dziewczyna staje się mężczyzną i może uwodzić inne kobiety bez obawy o brak akceptacji (Łojas, Dynarski 2010: 4849).

Rupp, Taylor oraz Shapiro przeprowadziły badania na grupie drag queens 801 Cabaret in Key West oraz grupie drag kings The Disposable Boy Toys, określanej przez członków jako „kolektyw polityczno-feministyczny" (2010: 276). Zauważyły one, że drag queens i drag kings cechowały różne drogi dojścia do bycia drag. Drag queens przekraczały swoją płeć już jako nastolatkowie, a niektóre z nich identyfikowały się jako osoby transpłciowe. U drag kings transformacja tożsamości była konsekwencją występowania jako drag king. W odróżnieniu od drag queens, to chęć bycia częścią queerowej społeczności przyciągnęła ich do spektaklu drag. Ponadto drag kings w swoich występach przywołują uniwersyteckie spojrzenie nawiązujące do gender oraz queer studies, przez co są trudniejsze w odbiorze niż drag queens (Rupp, Taylor, Shapiro 2010: 277).

\section{Metodologia badań własnych}

Badania prowadziłam metodą etnograficzną, ze szczególnym uwzględnieniem etnografii krytycznej oraz autoetnografii, przy czym w dużej mierze czerpałam również z metodologii queer. W ramach wybranej przeze mnie metodologii wykorzystałam dwie techniki zbierania danych - pogłębiony wywiad indywidualny oraz analizę treści.

Choć obecnie obie metodologie - ilościowa i jakościowa - traktowane są na równi, popularność etnografii była wynikiem rozczarowania metodami ilościowymi, które przez długi czas dominowały w naukach społecznych (Hammersley, Atkinson 2000). To ludzie są najważniejszymi elementami w organizowaniu ładu społecznego, bowiem "jednostki posiadają umiejętności językowe i interakcyjne, dzięki którym wytwarzają najważniejsze elementy życia codziennego" (Holstein, Gubrium 2009: 681). Autoetnografia skupia się na osobistym doświadczeniu badacza. Jedną z form autoetnografii, która w największym stopniu charakteryzuje moje badania, jest skupienie się na uczestnikach badań i ich historii - przy jednoczesnym uznaniu wpływu uczuć i przemyśleń badacza. Liczą się osobiste motywacje do podjęcia takiej, a nie innej tematyki, posiadana wiedza na temat 
zgłębianego zjawiska oraz to, w jaki sposób proces badawczy mógł zmienić samego badającego (Ellis, Adams, Bochner 2011).

Z nurtu etnometodologii wyrosła etnografia krytyczna, która wyraża niezadowolenie i zawód ideą obiektywnych nauk społecznych. Jak pisze Douglas Foley i Angela Valenzuela:

Etnografowie krytyczni są zwykłymi, uwięzionymi w kulturze śmiertelnikami, przemawiającymi z konkretnych miejsc określonych przez rasę, klasę, płeć, tożsamość seksualną. Wszystkie punkty widzenia reprezentują konkretne interesy i pozycje w hierarchicznym społeczeństwie, są więc »ideologiczne« w tym sensie, że są częściowe [...]. (2009: 316)

Jako jeden z typów etnografa krytycznego, Foley i Valanzuela wyróżniają działacza zaangażowanego w ruchy społeczne i środowiskowe (2009: 316).

Tematyka mojego artykułu jest zakorzeniona w teorii queer, która to równa się odrzuceniu konwencjonalnych i ortodoksyjnych metod (Halberstam 1998: 9-13). Metodologia queer kwestionuje konwencjonalne podejścia poprzez atakowanie ich wyłączne skupianie się na obiektywizmie, a także kwestionuje pogląd, że prawdziwa wiedza jest nienaruszona przez kontekst społeczno-kulturowy (Binnie 1997: 227).

Podstawową techniką, którą wykorzystuję w moich badaniach, jest indywidualny wywiad pogłębiony. Wydaje się on być najbardziej odpowiednim sposobem zbierania danych, ponieważ grupa, którą chcę zbadać, jest grupą nieliczną - podczas zbierania informacji udało mi się dowiedzieć jedynie o ośmiu drag kingach występujących w Polsce. Drugim istotnym powodem jest to, że dużą część wywiadów stanowią pytania dotyczące osobistego życia i poglądów badanych.

Jak zaznaczyłam wcześniej, drag kings w Polsce są grupą niewielką. Ze względu na własne zainteresowanie kulturą queerową już przed rozpoczęciem badań zdawałam sobie sprawę z istnienia czterech osób, dzięki którym dowiedziałam się o ośmiu występujących w Polsce performerkach. Udało mi się skontaktować z wszystkimi ośmioma osobami. Na moją prośbę 
pozytywnie odpowiedziały cztery z nich - DK Morfi, DK Vera Cruz, DK Gender Genetrix oraz DK Freddie, które ostatecznie stanowią moją grupę badanych².

Uzupełnieniem indywidualnych wywiadów pogłębionych jest analiza nagrań występów drag kingów w Polsce. W odróżnieniu od poprzedniej części badań, w tej skupiam się nie na motywacjach drag kingów, lecz na zewnętrznym odbiorze wyników ich pracy.

Jednostką analizy w moich badaniach było pojedyncze nagranie. Próbę stanowiło pięćdziesiąt pięć nagrań polskich drag kingów, czyli wszystkie filmy dostępne na portalu Vimeo ${ }^{3}$ oraz na kanale Youtube DK Freddiego ${ }^{4}$, a także nagrania własne z występów DK Morfi i DK Very Cruz we Wrocławiu (15.04.2014) oraz w Krakowie (17.05.2014). Jeśli nagrane występy się powtarzały, do badań wybierałam nagranie nowsze. Wyjątek stanowi jeden z występów DK Freddie - nowsze nagranie dotyczyło występu spontanicznego i nieplanowanego wcześniej, dlatego też do badań zdecydowałam się zakwalifikować nagranie starsze. Ponadto, jeśli ta sama piosenka lub ten sam występ były wykonywane kilkukrotnie - za każdym razem w innym składzie (powiększonym, pomniejszonym lub złożonym z innych drag kingów) - badaniami obejmowałam każdy z występów.

\section{Czym są performanse drag kings? Wyniki badań}

Główne pytanie, na które szukałam odpowiedzi w badaniach, dotyczy tego, na ile zjawisko drag kings można uznać za działalność w pewnym stopniu polityczną. Jako polityczność występu rozumiem zaangażowanie na rzecz ruchów LGBTQ, poruszanie tematyki nienormatywnej seksualności oraz płci jako konstruktu kulturowego. Uznałam, że w odpowiedzi na to pytanie pomóc może przenalizowanie sposobu, w jaki badane podchodzą do tematów, które mogą być poruszane w trakcie występów. Mam tu na myśli przede wszystkim kwestie gender, feminizmu oraz ruchów LGBTQ, jak również kwestię zaangażowania społecznego drag kingów.

\footnotetext{
${ }^{2}$ Wszystkie kodeksy etyczne podkreślają, że należy zapewnić badanym całkowitą poufność i nie ujawniać ich tożsamości. Jednak osoby występujące jako drag kings są niejako osobami publicznymi, więc ciężko o pełną anonimowość. W trakcie rozmów z respondentkami zapewniłam, iż nie ujawnię ich danych osobowych. Pytałam również o to, w jaki sposób chcą być przedstawiane w pracy. Wszystkie cztery osoby wyraziły zgodę, by używać ich pseudonimów scenicznych.

${ }^{3}$ http://vimeo.com/dragkingz [27.04.2014].

${ }^{4}$ https://www.youtube.com/user/DKFreddie/videos [27.04.2014].
} 


\section{Gender(bending?)}

Gdy pytałam badane o krótkie wyjaśnienie czym według nich jest płeć, wszystkie skupiały się przede wszystkim na opisaniu płci kulturowej, wspominając pokrótce o obecności płci biologicznej. Może to wynikać z faktu, iż ich działalność sceniczna skupia się na grze kulturowymi aspektami płci. Zapytałam badane o to, jak się identyfikują, jeśli chodzi o płeć. Zanim poruszę kwestie identyfikacji, chciałabym jednak przedstawić, jakie podejście mają badane do kwestii wpisywania siebie w różne kategorie.

Dla większości badanych drag kingów kategoryzowanie się jest istotne przynajmniej na niektórych etapach życia. Jak mówi DK Morfi: „Nawet jeśli jesteśmy anarchistami, jesteśmy w kontrofensywie, ale jesteśmy nimi, podpisujesz się pod tym" ${ }^{5}$. Również DK Gender Genetrix podkreśla, że nie można się zupełnie nie kategoryzować, ponieważ wszystko jest pewną „szufladką".

Choć DK Gender Genetrix uważa, że kategoryzowanie się jest ważne w określonych momentach, to denerwują ją oczekiwania społeczeństwa odnośnie tego, że powinna wyraźnie się określić:

Wkurza mnie to, zarówno w kwestii kobieta-mężczyzna i to, że dominująca części społeczeństwa każe mi się określać jako kobieta heteroseksualna [...]. Jeżeli chodzi o moją seksualność, jeżeli nie wyglądam w pewien sposób, to ludzie od razu zakładają, że jestem hetero, jeżeli mam długie włosy, noszę obcasy, wszyscy od razu myślą, że jestem hetero i sobie faceci dają prawo do tego, żeby mnie podrywać.

Gorzko komentuje także działania wewnątrz społeczności LGBTQ, które - mimo że głoszą hasła o równości, różnorodności i prawie do bycia sobą - same wykluczają osoby nieprzystające do oczekiwań tych społeczności. Badana podkreśla, że w środowisku LGBTQ jest pewien nacisk na to, aby odpowiednio wyglądać - jeżeli ktoś prezentuje typ kobiety, która powszechnie zostałaby uznana za heteroseksualną, to często doświadcza pewnego rodzaju wykluczenia.

Fakt, że ludzie potrzebują kategoryzacji, żeby wiedzieć, kto jest „swój”, a kto nie, jest dla DK Gender Genetrix niezrozumiały i bezsensowny. Dlatego też bardzo odpowiada jej podejście queer mówiące

\footnotetext{
${ }^{5}$ Cytaty stanowią fragmenty transkrypcji wywiadów z performerkami.
} 
o płynnych tożsamościach. DK Vera Cruz preferuje określenie „ometkowanie”, które wskazuje na możliwość użycia wobec siebie wielu kategorii.

Można zauważyć powiązanie między identyfikacją drag kingów a ich poglądami na temat wpisywania siebie w kategorie. DK Freddie krótko odpowiedziała, że identyfikuje się jako kobieta. Również DK Gender Genetrix mówi, iż jest silnie przywiązana do kobiecej tożsamości. DK Morfi nie czuje potrzeby określania się w kwestii płci - twierdzi, że czuje się dobrze ze sobą. Może powiedzieć, że jest kobietą (ponieważ ta kategoria pasuje do niej zarówno w kwestii płci biologicznej, jak i kulturowej), natomiast nie ma także problemu z tym, aby to określenie podważyć.

Jak pisałam wyżej, DK Vera Cruz nie jest zwolenniczką określania siebie tylko jedną kategorią, stąd też nie dziwi fakt, że wychodzi ona poza binarne opozycje kobieta-mężczyzna. Wymienia cztery określenia, z którymi się identyfikuje: bigender, trans, genderqueer oraz queer.

W przypadku zjawiska drag kings interesującym zagadnieniem jest to, czy genderbending, który jest przecież nieodłączną częścią występu drag kingowego, jest także widoczny w codziennych praktykach badanych. W związku z tym nasuwa się również pytanie, czy naginanie płci kulturowej w życiu prywatnym przekłada się w jakimś stopniu na genderbending na scenie.

Wszystkie cztery badane uważają, że w pewien sposób naginają swoją płeć. Jednak w przypadku dwóch z nich - DK Freddie oraz DK Gender Genetrix - genderbending przejawia się w niewielkim stopniu. DK Freddie uważa, że przekracza swoją płeć, lecz nie robi tego z użyciem elementów wizerunkowych (jak bywa najczęściej), a raczej wykorzystuje osobowość oraz zachowanie: „jakieś moje decyzje, nawet wyjazdu do pracy, o nieposiadaniu dzieci, to też jest jakieś wyjście poza płeć, w tym społecznym znaczeniu na pewno". U DK Gender Genetrix genderbending dotyczy sfery wyglądu, jednak również nie jest on tak bardzo widoczny jak u pozostałych dwóch drag kingów.

DK Vera Cruz, zgodnie z identyfikacją genderową, nagina swoją płeć w znaczącym stopniu. Płeć uważa za kostium i bawi się owym przebraniem. Uważa ponadto, że przekraczanie płci równa się pewnego rodzaju katharsis, co zauważa w przypadku uczestniczek warsztatów drag kingowych. Wydaje się, że to DK Morfi przekracza płeć w największym stopniu ze wszystkich badanych - 
szczególnie, jeśli chodzi o wygląd zewnętrzny. DK Vera Cruz przytacza historię, która podkreśla bardzo androgyniczny i trudny do odczytania wygląd DK Morfi:

Wracałyśmy kiedyś z występu [...] i DK Morfi prowadziła, i byłyśmy strasznie zmęczone [...], i akurat tak na DK Morfi trafiło, na jej dyżur za kierownicą, że wjechałyśmy już w teren zabudowany, ona oczywiście się rozpędziła, no i nas zatrzymała policja. DK Morfi uchyla okno, lato, ona podkoszulek, okulary przeciwsłoneczne, no i uchyla to okno, a policjant na to: »Dzień dobry pani czy panu, jak mam się zwracać...?«

DK Morfi swoją androgyniczność łączy także z występami scenicznymi. Lubi performanse, w których przechodzi z jednej płci do drugiej, czy też balansuje na granicy między płciami tak, aby było to niedookreślone: „już mi mówili, że jak się przebieram za kobietę, to wyglądam jak trans, jak za mężczyznę, to w sumie po co się przebrałam".

Podsumowując, badane drag kingi odrzucają sztywne dychotomie. Choć niektóre z drag kingów, z którymi rozmawiałam, używają w stosunku do siebie określenie "kobieta”, to zauważają jednak, że przekraczają stereotypowy wizerunek kobiety. Wszystkie badane uważają także, że - w mniejszym lub większym stopniu - przekraczają swoją płeć biologiczną i łączą to nie tylko ze swoim wyglądem czy charakterem, ale także z występowaniem na scenie.

\section{Seksualność i zaangażowanie społeczne}

Wszystkie z badanych, były lub są - w różnym stopniu - aktywistkami. DK Freddie przez długi czas udzielała się w ruchu feministycznym, ale także - w mniejszym stopniu - w ruchu queerowym. Była współorganizatorką Dni Cipki, natomiast w czasie pobytu w Londynie zaangażowała się w "korpo świat LGBT". Inna badana, DK Gender Genetrix, również ma nastawienie mocno feministyczne, popiera ruchy prozwierzęce oraz wspiera działania ruchów LGBTQ - podczas swoich studiów w Krakowie była współorganizatorką Queerowego Maja. DK Vera Cruz wspomina, iż została tak wychowana, by nie godzić się na niesprawiedliwość i nierówności. Obecnie działa w łódzkim stowarzyszeniu Fabryka Równości. 
DK Morfi obecnie nie udziela się w tego typu ruchach, choć przez długi czas była zaangażowana w ruchy feministyczne, lesbijskie oraz queer. Jak twierdzi, nie odczuwa już potrzeby walki. Mimo to jest zwolenniczką aktywizmu, a szczególnie podziwia osoby, które „mieszają polityczne z prywatnym, wtedy to ma dużo większe znaczenie i dużo bardziej oddziałuje, bo ludzie uwielbiają oglądać Big Brother i wszystkie te show".

Jak widać, większość badanych jest nastawionych mocno aktywistycznie, co może sugerować, że w ich występach można będzie odnaleźć elementy politycznego zaangażowania. Jednak - w kontekście możliwej polityczności występów - istotnym zagadnieniem wydaje się być też pytanie o tożsamość seksualną badanych.

Wszystkie badane określają się jako osoby nieheteroseksualne. DK Freddie określa się jako lesbijka, choć nie jest to kategoria, która opisuje ją w stu procentach. Mówi, że do tego określenia jest jej najbliżej; dodatkowo używa owej kategorii ze względów politycznych. „Dla mnie nie jest istotna tożsamość lesbijki jako takiej, ale właśnie to, że mogę być niehetero, i że jakby jest przestrzeń na to, żebym się nie musiała tak dookreślać" - mówi.

DK Morfi nie wie, jak będzie określać się w przyszłości, choć obecnie uważa, że najbliżej jest jej do biseksualności. Cechą, która silnie charakteryzuje jej życie, jest zmiana - dlatego nie potrafi określić, w jakim kierunku podąży. Płynność seksualności podkreśla także DK Gender Genetrix. W momencie wywiadu zdecydowanie czuje, że jest lesbijką, jednak - mimo wszystko - w tej kwestii wolałaby się nie określać. DK Vera Cruz definiuje siebie jako osobę biseksualną. Podkreśla także, że ważnym elementem jej seksualności jest poliamoria. Mówi, że zależy jej na odkłamywaniu mitów na temat biseksualności, gdyż jest to temat zupełnie pomijany w dyskursie publicznym; biseksualiści są społecznie niewidoczni, a co za tym idzie, funkcjonują na ich temat silne stereotypy - również w społeczności LGBTQ.

Wszystkie badane mają doświadczenia w działalności w różnego typu ruchach społecznych. Niektóre udzielały się w bojówkach feministycznych, inne w zarejestrowanych stowarzyszeniach lub w nieformalnych grupach, jednak każda z nich uczestniczyła w działaniach ruchów na rzecz osób nieheteronormatywnych oraz popiera takie akcje. Połączywszy aktywistyczną naturę badanych z ich 
tożsamością płciową, tożsamością seksualną oraz z ich poglądami, można wnioskować, iż występy w pewnym stopniu będą miały polityczny charakter.

\section{Występy drag kings}

Początek działania jako drag kings wiązał się dla badanych z przypadkowym zdarzeniem bądź z chęcią dobrej zabawy. DK Morfi zajmuje się drag kingowaniem najdłużej, bo od około 10 lat. O jej występach zadecydował zbieg okoliczności. DK Morfi była współorganizatorką pewnego festiwalu, gdzie jako drag kingi występowały jej znajome, które to namówiły ją do wspólnego występu. Dla DK Freddie, podobnie jak dla DK Morfi, to przypadek zadecydował o rozpoczęciu przygody z drag. Na imprezie crossdressingowej zdecydowała się wcielić w rolę Freddiego Mercurego:

W momencie, gdy puściłam muzykę Queen, i jak zaczęłam do niej śpiewać i sobie tańczyć, to ludzie stanęli w kole, wszyscy stali i się gapili, bo generalnie okazało się, że przypominam Freda [...]. I krótko potem, tydzień, dwa tygodnie później, była jakaś impreza genderbender i był jakiś konkurs drag kingowy, koleżanka namówiła mnie żebym tam poszła, i właśnie było bardzo super przyjęcie wtedy, nikt nie był wywoływany na bis, tylko ja, więc jestem z siebie niesamowicie dumna.

Początek kariery scenicznej DK Very Cruza to fascynacja osobami, które przekraczają płeć. Dlatego też wraz z koleżanką wpadły na pomysł, by spróbować wystąpić jako drag kings. DK Vera Cruz miała swój pierwszy występ w lipcu 2012 roku - od tego czasu wielokrotnie występowała w różnych miejscach w Polsce. Dla DK Gender Genetrix pierwsze informacje o istnieniu drag kingów zbiegły się w czasie z jej pierwszym występem. W 2013 roku współorganizowała ona festiwal Queerowy Maj w Krakowie, podczas którego odbywały się warsztaty drag kingowe, w których zdecydowała się wziąć udział.

Przede wszystkim mi się to wydało przepotwornie zabawne [...], ten sam proces, że te wszystkie ubrania były na nas za duże, że miałyśmy wybierać, czy jedna chce być takim bardziej alfonsem, czy jedna chce być koszykarzem, druga jakimś żulem. (DK Gender Genetrix) 
Spośród wszystkich badanych to DK Gender Genetrix ma najmniejsze doświadczenie z występami drag kings. Do momentu wywiadu jako drag king wystąpiła trzykrotnie.

\section{Wybór postaci}

Ważną różnicą między drag queens a drag kings jest to, iż te drugie nie skupiają się na pokazywaniu tylko jednej postaci w trakcie swoich występów (Konarzewska 2010: 34). Jak wynika z badań, nie jest to do końca prawdą, ponieważ jedna z moich badanych - DK Freddie - koncentruje się wyłącznie na odgrywaniu Freddiego Mercurego. Wybrała właśnie tego bohatera, ponieważ jest fanką Frediego i czuje się z nim wewnętrznie związana. Jednak sama podkreśla, że jej przykład jest wyjątkiem (przynajmniej na scenie polskiej). Stąd też nasuwa się pytanie: "Jakie postaci odgrywają drag kingi i w jaki sposób je wybierają?"

Różne osobowości, charaktery i różne doświadczenia sprawiają, że występy polskich drag kingów niosą za sobą zróżnicowane treści i interpretacje. Zarówno dla DK Very Cruza, jak i dla DK Morfi, wybór piosenki do występu odgrywa dużą rolę w wyborze postaci. DK Vera Cruz, oprócz odgrywania postaci z popkultury, lubi także wykonywać performanse, których bohaterami są zniewieściali mężczyźni lub takie, które polegają na przejściu postaci z jednej płci na inną. DK Vera Cruz podkreśla także, że postać na scenie to kawałek jej samej: „Jest znacznie bardziej przegięta i na co dzień bym się tak nie ubrała, ale gdyby to nie było obarczone jakimś takim ryzykiem społecznym, [...] to chodziłabym tak na co dzień". Drag kingowanie pozwala jej swobodnie poczuć się w męskiej skórze i wydobyć męską część siebie.

Podobnie jak DK Vera Cruz, DK Morfi często występuje jako postać, która na scenie przechodzi z jednej płci w inną, co - jak sama podkreśla - ma duży związek z jej androgynicznością. Dodaje, iż postać, którą odgrywa, czy też sam przebieg występu, muszą być w jakimś stopniu związane z obecną sytuacją performerki.

Postacie męskie są bohaterami prawie wszystkich umieszczonych w internecie występów, które stanowiły moją próbę do analizy treści. Wizerunek męskości przedstawiany w performansach jest zróżnicowany i ciężko wskazać typ, który pojawia się najczęściej. Niektóre z występów przedstawiają bohaterów stereotypowo męskich, takich jak maczo podrywający kobiety i skupiający uwagę na seksualności. Popularną postacią jest raper bądź typ chłopaka z boysbandu, ale w 
występach czasami pojawiają się również postacie przegiętych gejów, czy też mężczyzn całkowicie niewyróżniających się z tłumu.

Tylko w jednym przypadku na scenie pojawił się nie mężczyzna, lecz postać transseksualna, zaś w kilkunastu występach obecne były postacie kobiece. Zdarzało się tak podczas występów, które tworzyło kilku drag kingów, jak również w przypadku performansów, gdzie bohater na scenie zmieniał się w postać odmiennej płci. Większość transformacji polegała na przejściu od postaci męskiej do postaci kobiecej. Przykładem tego rodzaju performansu jest występ DK Tivv wraz z DK Dieterem Van Tease, gdzie występ rozpoczyna się od postaci męskich, które to wraz z upływem czasu zmieniają się w uwodzicielskie kobiety.

Przemiany postaci w czasie występów nie polegają jednak tylko na przejściu z kobiety w mężczyznę, czy na odwrót. W występach można zauważyć także transformacje postaci w obrębie jednej płci. Wśród takich przemian bohaterów warto odnotować zmiany, które można uznać za queerowe, jak ma to miejsce w przypadku występu DK Dietera Van Tease, gdzie tytułowy "kibol" zmienia się w drag queen w spódniczce i z doczepionymi skrzydłami motyla.

Z powyższych wypowiedzi oraz analizy występów można wywnioskować, że najprostsza definicja drag kings - mówiąca, że to kobieta (czy też osoba dowolnej płci) odgrywa męskość - nie do końca jest definicją prawdziwą. Performerki nie wybierają jedynie postaci męskich (czy to agresywnych maczo, czy zniewieściałych homoseksualistów), ale - co ważne - zdarzają się także występy w rolach osób pomiędzy płciami oraz występy w roli kobiet. Można więc uznać, że najbliższa prawdzie, spośród definicji podanych przeze mnie w pierwszej części artykułu, jest definicja stworzona przez Rupp, Taylor i Shapiro, która wspomina o tym, że drag kings mogą odgrywać także kobiecość (2010: 276). Widać także, że zabawa z płcią ma dla występujących drag kingów duże znaczenie. Spora część występów opiera się na transformacji postaci i wielokrotnym wykraczaniu poza płeć.

\section{Publiczność}

Badane zauważają, iż zdecydowana większość występów odbywa się miejscach, gdzie publikę tworzą środowiska queerowe. Zdarzają się też jednak występy przed inną publicznością. Jak wspomina DK Morfi: 
Pierwszy autograf, jaki dałyśmy dawno temu, to było zupełnie od takich ludzi 60+, kobieta z mężczyzną przyszli zobaczyli i się bawili, myśleli że to jakieś przebieranki. No a w sumie, co to ma więcej być? Zwykła zabawa, więc tam, wiesz, dopóki nie emanujesz może za bardzo tym seksem czy wibratorami, to się ludziom podoba.

Publiczność stanowią przede wszystkim kobiety, chyba że impreza skierowana jest do innego środowiska - DK Vera Cruz podaje przykład występu w warszawskim klubie Toro, który to jest klubem gejowskim. DK Freddie podkreśla także, że publiczność często związana jest nie tylko ze środowiskiem queerowym, ale także feministycznym czy też - szeroko pojętym - środowiskiem alternatywnym, do którego można zaliczyć występy przed publicznością w squatach.

Słowa drag kingów potwierdza analiza występów. Nagrania performansów dostępnych w Internecie w większości pochodzą z wydarzeń, które odbywały się podczas imprez skierowanych do środowiska LGBTQ lub środowiska feministycznego (np. podczas wydarzenia kończącego Queerowy Maj w Krakowie, imprezy promującej akcję Miłość Nie Wyklucza, podczas urodzin UFY ${ }^{6}$ ) albo w klubach, których działalność skierowana jest właśnie do osób związanych z tymi środowiskami (np. we wrocławskim Coffee Planet czy warszawskim Toro).

\section{Motywacje i cele występów drag kings}

Ta część artykułu w największym stopniu pomoże w odpowiedzi na pytanie, czym jest występ drag kings. W trakcie wywiadów z badanymi poruszone zostały kwestie dotyczące tego, kiedy czują one satysfakcję z występów, co daje im wcielanie się w postać mężczyzny i czym jest dla nich drag kingowanie. Wypowiedzi badanych kształtują ciekawy obraz sceny drag kingowej w Polsce. Motywacje i cele performerek związane z tworzeniem drag kingowych performansów są różne. Z wywiadów wynika, iż można je podzielić na trzy główne kategorie: zabawę, przyczyny osobiste oraz polityczne zaangażowanie.

6 "UFA jest otwartą kobieco-queerową centrą kulturalno-społeczną non-profit, działającą na zasadach niehierarchicznych, prowadzoną przez kolektyw wolontariuszek_szy i utrzymywaną z grantów i dotacji" (<http://www.u-fa.pl/index.php?option=com_content\&view=article\&id=74\&ltemid=36>, dostęp: 04.06.2014). 


\section{Zabawa}

Wszystkie badane wyróżniają zabawę jako istotny element ich performansów. Dla DK Gender Genetrix pierwszą motywacją była chęć rozrywki. Świetna zabawa była dla niej impulsem do tego, aby zająć się drag kingowaniem. Elementem zabawy jest dla niej także możliwość przeniesienia się na chwilę do innej rzeczywistości, w której płeć nie musi być rzeczą tak oczywistą, jaką jest w świecie realnym.

Dla pozostałych badanych kwestia zabawy również jest niezwykle istotna. Podkreślają one, że występy drag kingowe są przede wszystkim rozrywką - chcą żeby zarówno one same, jak i osoby z publiczności czerpały radość z uczestniczenia w takim performansie. Dodatkowo DK Morfi mówi, że występy drag mają dla niej wymiar parodystyczny oraz przekazują pozytywną energię, zaś DK Vera Cruz nie rozpatruje swoich występów w feministycznym kontekście, wiedząc jednak, że są osoby, dla których jest to istotna część dragowania.

\section{Motywacje osobiste}

Najwięcej powodów, z jakich badane decydują się na występy drag, mieści się w obrębie kategorii, którą nazwałam motywacjami osobistymi. Dotyczą one tego, co odczuwają performerki w związku ze swoimi występami i co te występy im dają.

Dla DK Freddiego główną motywacją była przede wszystkim chęć wcielenia się w postać Freddiego Mercurego. Podkreśla ona jednak, że jej występy różnią się od występów pozostałych drag kingów:

Drag kingi interesują się odgrywaniem tej płci męskiej, jakby niezależnie od postaci. Natomiast ja nie wychodzę poza postać Freddiego, ja się śmieję, że jestem bardziej „drag Fredem” niż drag kingiem.

Najczęściej wymienianym powodem z tej kategorii była chęć znalezienia się w centrum uwagi. DK Morfi podkreśla, że na scenie może skonfrontować się z własnymi myślami, a także może poczuć się narcystycznie i "połechtać" swoje ego: 
Ja kiedyś tysiąc razy mówiłam, że nie, nie, nie, ale tak, tak, tak, to jest jak najbardziej narcystyczna opcja. Jak najbardziej, no na stówę, nie powiesz mi, że ktoś cię na siłę na scenę wpycha. Skoro tam jesteś, to znaczy, że chcesz się pokazać.

Również dla DK Very Cruza jedną z motywacji jest chęć bycia na scenie i występowania, jako że dzięki występom drag kingowym można osiągnąć namiastkę sławy.

Drag kingi wyszczególniają także fakt, że występy są dla nich możliwością wewnętrznego rozwoju oraz lepszego poznania siebie. DK Gender Genetrix podkreśla, że występy pozwalają jej odkryć, w jaki sposób przeżywa przekraczanie płci i seksualności. Na podobną motywację wskazuje DK Morfi, która mówi, że dzięki występom przerabia też własne emocje:

to jest takie trochę terapeutyczne, że bierzesz coś, co ci nie pasuje w jakichś emocjach, w stroju, w seksie też, bo tam też jest dużo seksualnych elementów i wywalasz to na scenę, przejaskrawiasz, przerysowujesz, ośmieszasz, ale inspiracją jest jakby ten moment, w którym jestem obecnie.

Dla niej występ jako drag king jest też w pewnym sensie parodią samej siebie - zachowań, ale też cech charakteru.

Duża część motywów krąży wokół zagadnienia przekraczania płci czy przekraczania siebie. DK Gender Genetrix mówi, iż w czasie występów chce poczuć się kimś innym, mając ochotę dobrze się bawić. Performans drag king równa się dla niej ucieczce od rzeczywistości przepełnionej powagą i wszechobecnym narzekaniem, gdyż w świecie drag kingowym może zbudować tę rzeczywistość od początku. W życiu DK Morfi bardzo istotna jest zmiana, co według niej fantastycznie sprawdza się na scenie. Wspomina też o tym, że w czasie występów może przekraczać stereotypy płciowe, tworzyć wciąż nowe postacie i zmieniać je bez konsekwencji. Dla DK Freddiego drag kingowanie jest nie tylko doświadczeniem samego przekraczania płci, ale poniekąd równa się także przekroczeniu siebie, aby stać się inną osobą - w tym przypadku Freddim, który jest dla performerki niewyczerpanym źródłem energii. 
Występy mają dla badanych także wymiar energetyczny i duchowy. DK Morfi mówi, iż występy są dla niej pewnym impulsem, doładowaniem energii. Dla DK Gender Genetrix ważne jest odczuwanie przyjemności na scenie oraz poczucie kontaktu z publicznością. Podkreśla, że przekraczanie płci na scenie ma znaczenie poniekąd transcendentalne:

Taki trochę szamańsko-energetyczny, taki szamański właśnie. Bo to jednak jest wydobywanie z siebie pewnego potencjału, który jest inny, jest to inna energia niż ta, którą w większości masz na co dzień [...]. Ja czuję, że jest to wzniesienie na inny poziom energetyczny i takie doznanie może czasem oczyszczać z jakichś innych doznań, traum.

Osobiste motywacje - wyrażone w różny sposób przez badane - obracają się wokół podobnych zagadnień. Do tej kategorii motywacji zaliczyć można potrzebę bycia na scenie i pokazywania się przed publicznością, jak również możliwość przekraczania płci oraz tożsamości. Ważnymi motywacjami wydają się być też pragnienie poznania siebie przez performerki oraz energia płynąca z występów.

\section{Zaangażowanie polityczne}

Zaangażowanie polityczne jest trzecią kategorią, którą można zauważyć w wypowiedziach badanych. Dwie główne podkategorie zaangażowania, które wyłaniają się z badań, to poruszanie kwestii feministycznych oraz tematyki LGBTQ.

Według DK Freddiego, w przypadku drag kings często mamy do czynienia z aktywistycznym, feministycznym przekazem; jednak ona na sama jest wyjątkiem wśród moich badanych. DK Freddie podkreśla, że występ nie ma dla niej nic wspólnego z zaangażowaniem politycznym (czy to w ruch feministyczny, czy w kwestie LGBTQ), a drag kingowania nie rozpatruje jako formy aktywizmu. Wyłącznie interpretacja występów DK Freddiego może wskazywać na pewien aspekt polityczności, czyli queerowość obecną w jej występach: „[Dziennikarz] pisał - to mi się spodobało - że jestem lesbijką, która występuje jako mężczyzna, ale przegięty gej, który z kolei próbuje udawać maczo". Również DK Vera Cruz wskazuje, iż choć występy drag kings w dużej mierze są zabawą, to jednak niosą za sobą pewien feministyczny czy genderowy podtekst. Sama jednak nie rozpatruje swoich występów w takich kategoriach. 
Dla DK Morfi występ jako drag king wynikał dawniej z pobudek feministycznych, czyli głównie potrzeby walki z patriarchatem i męską dominacją. Twierdzi, że to w dalszym ciągu aktualne, jednak nie w aż tak dużym stopniu jak niegdyś. Jej obecne występy wynikają raczej z chęci pokazania, że scena dragowa jest też dla kobiet. DK Morfi zaznacza, że występy drag kingowe polegają częstokroć na parodii przerysowanej męskości faceta maczo - zadufanego w sobie, skupiającego uwagę tylko na seksie - co może mieć podtekst feministyczny i wskazywać nie tylko na wyśmianie tego typu mężczyzny, ale na wyśmianie patriarchatu w ogóle.

$\mathrm{Na}$ walkę z patriarchatem wskazuje również DK Gender Genetrix. Traktuje ona występy drag kingowe w kategoriach politycznych, mimo że jej performansy - jak dotąd - nie były w dużej mierze nasycone elementami ideowymi. Twierdzi ona, że drag kings demaskują konstrukt kulturowy, jakim jest płeć. Kolejny motywujący czynnik odkryła dopiero później, gdy zobaczyła, że drag jest wyzwalający. Według DK Gender Genetrix wcielenie się w rolę drag kinga ma wartość emancypacyjną:

Czujesz zupełnie inną energię, [...] wykorzystujesz te stereotypowe pojęcia męskości, bawisz się nimi i wczuwasz się w rolę mężczyzny. I nagle okazuje się pamiętam, że na mnie zrobiło to duże wrażenie - że jak masz tą skarpetę w majtkach, to nagle zaczynasz szerzej siadać, zajmujesz więcej przestrzeni i masz takie większe przyzwolenie, że świat należy do ciebie, bo przestrzeń należy do ciebie.

DK Vera Cruz, która nie widziała w swoich występach elementów feministycznych, w wypowiedziach wskazuje na pewnego rodzaju aktywizm w kategoriach queerowych. Dla niej cały występ ma mocny przekaz queerowy, a jego najcenniejszy element to, jej zdaniem, "mieszanie właśnie płci, że mam obwiązane cycki i wąsy, ale do tego jestem w sukience, to jest queer w czystej postaci". Również DK Morfi podkreśla, iż obecność na scenie pozwala przekraczać płeć, bawić się nią, odsuwając się od heteronormy.

W występach drag kingowych bohaterowie nie są wyłącznie stereotypowymi heteroseksualnymi mężczyznami. DK Vera Cruz mówi, że kiedy gra postacie gejowskie, stara się wybierać mężczyzn z 
publiczności i to właśnie z nimi tworzy interakcje. Dla niej występ ma skłonić publiczność do zastanawiania się, czy na pewno są - i chcą być - normatywni.

DK Morfi dodaje, że w jej występach były obecne elementy aktywistyczne, których jednak nie można zaklasyfikować do żadnej z powyższych kategorii:

Na przykład były jakieś szczyty G8 i były tam ścięcia z policją i tak dalej, to myśmy robiły takie kawałki - policjant kontra manifestujący. Ja robiłam też coś kontra pedofilii, naprawdę, przypominam sobie, że robiliśmy taki kawałek, wiesz, mała dziewczynka i ojciec znęcający się nad nią.

Obecnie DK Morfi nie czuje już silnej przynależności do ruchu, dlatego też aktywizm w jej występach nie jest już tak widoczny.

\section{Wnioski z analizy występów}

Większość nagrań dostępnych w Internecie przedstawia występy, które - okiem postronnego obserwatora - nie wydają się posiadać elementów wskazujących na zaangażowanie polityczne. $\mathrm{Na}$ pewno nie widać tego rodzaju elementów w występach DK Freddiego, które faktycznie są wyłącznie wcieleniem się w rolę Freddiego Mercurego.

Intencją wielu z występów pozostałych drag kingów wydaje się być jedynie zabawa. Są to performansy między innymi parodystyczne, jak na przykład parodia koncertu wokalisty zespołu Feel lub parodia znanego utworu "Somebody that I used to know", w którym kilka osób wykonuje go na jednej gitarze. Znaleźć można także cały szereg występów będących przedstawieniem określonego typu męskości - jak chociażby rapera czy eleganckiego, romantycznego mężczyzny.

Duża część występów porusza tematykę erotyczną. Niektóre z nich nie wydają się być przykładami zaangażowania politycznego. Jednym z takich performansów jest występ „Punkt G" DK Tivv czy też performans, w którym DK Morfi przedstawia masturbującego się chłopaka. Istnieje jednak rodzaj występów, w którym element erotyczny może być postrzegany jako niosący za sobą ideologiczne przesłanie. Przede wszystkim są to występy, w których erotyka dotyczy osób tej samej płci. Duet DK 
Morfi oraz DK Tivv przedstawia trzy performansy, które w największym stopniu wydają się być polityczne właśnie przez erotykę.

Pierwszy występ rozpoczyna się postacią rapera, co jest dość typowe jak na drag kingowe performanse. Można odnieść wrażenie, że tekst piosenki śpiewany jest do kobiety, jednak po chwili na scenę pewnym krokiem wkracza bardzo androgyniczny, "przegięty” gej. Akcja tego performansu okazuje się być nasycona elementami homoerotycznymi. Inny przykład to występ, którego bohaterami jest dwójka mężczyzn - jeden bardzo silny i dominujący, a drugi spokojny. Pierwszy z nich wykonuje wobec drugiego seksualne ruchy, a także rozpina jego spodnie, po czym wyciąga z nich pejcz. Jednak najbardziej queerowy jest występ trzeci. Początkowo wydaje się, że scena będzie dotyczyć kobiety i mężczyzny (pary heteroseksualnej). Wraz z rozwojem wydarzeń wychodzi jednak na jaw, iż kobieta posiada penisa, a mężczyzna - biust.

Aspekt feministyczny można odczytać przede wszystkim z występów, których bohaterami są mężczyźni maczo skupiający swoją uwagę głównie na kwestiach seksualnych. Według mnie performans "WTF" DK Dietera Van Tease może posłużyć za wzorcowy przykład występu mocno zaangażowanego politycznie - zarówno w kwestiach feministycznych, jak i gender. Występ rozpoczyna się postacią rapera trzymającego w ręku perukę jednoznacznie symbolizującą kobietę, która stała się obiektem seksualnym. Przekaz tego fragmentu można odczytać jako wyśmianie patriarchalnej kultury, w której kobieta podlega mężczyźnie. W pewnym momencie występu performerka rozciąga transparent z napisem "fuck your gender", po czym zrzuca męski strój i przeobraża się w kobietę, co można odczytać jako zachętę do zabawy z płcią i odrzucenie sztywnych dychotomii. Ów występ zawiera również queerowy przekaz, ponieważ na koszulce jednej z postaci widnieje wizerunek dwóch całujących się kobiet.

Na zabawę z płcią (którą również można odczytywać jako zaangażowanie polityczne w kwestie gender) wskazują także występy innych drag kingów. Chciałabym wspomnieć o dwóch przykładach, które wydają się być najmocniej skupione na tym aspekcie. Pierwszym z przykładów jest performans DK Morfi. Występ zaczyna się od przemiany postaci rockmana w postać kobiecą posiadającą zarost i koszulkę z napisem: "no gender, no sex, no problem”. Drugi występ, który wydaje się być istotny, to performans tworzony przez dwóch drag kingów - DK Tivv i DK Dietera Van Tease. Początkowo postaci występują w strojach męskich, jednak z czasem odkrywają, że nie są 
mężczyznami, i zaczynają się wzajemnie rozbierać, by wreszcie skończyć występ w roli uwodzicielskich kobiet.

Ciężko znaleźć w występach elementy, które - jak ma to miejsce w przypadku występów drag queens - można jednoznacznie zaklasyfikować jako kamp. Dostrzegam jedynie dwie kwestie wskazujące na kampowość występów. Po pierwsze, moją uwagę zwróciły występy w roli postaci poniekąd przejaskrawionych, jak na przykład - używając języka potocznego - przegięty gej, stereotypowy maczo, czy "głupiutka” i niepoważna kobieta. Drugi przykład jest, moim zdaniem, o wiele ciekawszy. DK Dieter Van Tease w jednym ze swoich występów skupia się na postaci Jezusa, i w tej właśnie sytuacji można zauważyć zaangażowanie polityczne, które przejawia się poprzez kamp. Susan Sontag w eseju "Notatki o kampie” pisze, że kamp "wyraża zwycięstwo [...] ironii nad powagą" (1979: 319). Wydaje się, że omawiany fragment występu doskonale to ilustruje - podczas performansu DK Dieter Van Tease wykorzystuje ironię oraz strategie mające na celu przerysowanie bądź wyśmianie postaci w naszej kulturze niezwykle ważnej i traktowaną z powagą. Sądzę jednak, że wyśmiana zostaje nie tyle sama postać Chrystusa, co kultura wynosząca pod niebiosa normy tworzone przez chrześcijaństwo.

Podsumowując - w występach badanych drag kingów znajduje się wiele elementów, które można zaklasyfikować jako zaangażowanie polityczne. Przede wszystkim dotyczy to kwestii feministycznych oraz zagadnień dotyczących społeczności LGBTQ. Mimo to wiele występów nie przejawia żadnych przesłanek do tego, by uznać je za element politycznego zaangażowania. Z analizy wypowiedzi badanych wynika, że przeważają motywacje osobiste - w wypowiedziach badanych oraz w ich występach trudno dostrzec związek z kampem. Z moich badań wynika, że performanse są przede wszystkim formą zabawy z wizerunkiem i płcią, a szczególne znaczenie dla badanych mają osobiste korzyści, które owa aktywność im przynosi.

\section{Podsumowanie}

Główną kwestią, którą chciałam rozstrzygnąć w toku moich badań, było pytanie o to, czym na gruncie polskim jest występ drag kings. Czy performans drag kings - przyjąwszy, że jest on analogiczny do zjawiska drag queens - cechuje przede wszystkim kampowość? Czy może, zgodnie z podejściem badaczek i badaczy opisujących różnice między oboma typami dragu, drag kings wyrażają zaangażowanie polityczne poprzez swoje występy? 
W badaniach zajmowałam się grupą osób, do których dotrzeć jest niełatwo. Wielokrotnie podkreślałam fakt, że w Polsce liczba performerek drag, o których udało mi się dowiedzieć podczas wstępnych rozmów z badanymi (jeszcze przed rozpoczęciem właściwego procesu badawczego) wynosi zaledwie osiem osób. W przypadku badania grup, których liczebność można określić w dziesiątkach czy setkach tysięcy, znalezienie ośmiu osób wyrażających chęć spotkania się z badaczem nie wydaje się być zadaniem wyjątkowo trudnym. W moim przypadku znalezienie ośmiu osób oznaczało przekonanie całej populacji do wzięcia udziału w badaniach. Zważywszy jednak na wielkość grupy, którą chciałam zbadać, moją przewagą było to, iż mogłam się skontaktować z każdą z wybranych osób z osobna. Prośby i zaproszenia do udziału w badaniu zostały rozesłane do wszystkich osób, jednak finalnie udało mi się porozmawiać z czterema performerkami. Mimo że stanowią one połowę populacji, nie można ze stuprocentową pewnością powiedzieć, iż badania odzwierciedlają podejście całej grupy drag kingów w Polsce. Jak można wywnioskować z wyników analiz występów oraz motywacji performerek, w wypowiedziach badanych zauważalne są pewne punkty wspólne - w wielu miejscach owe wypowiedzi całkowicie się jednak różnią, mając silnie indywidualny charakter. Z tego powodu chcę podkreślić, iż otwartym pozostaje pytanie o to, czy wyniki moich badań na pewno odnoszą się do całej populacji drag kingów w Polsce.

Pierwszą rzeczą, którą chciałabym poruszyć, jest kwestia definiowania drag kingów. Jak pokazałam w pierwszej części artykułu, większość definicji - a szczególnie tych, które w najprostszy sposób starają się ująć to zjawisko - podkreśla fakt, iż drag king na scenie prezentuje męskość i wciela się w męskie postacie. Z moich badań wynika, że wedle tych definicji moje badane wcale nie są drag kingami. Po przeprowadzonej analizie wypowiedzi oraz występów polskich performerek drag zdefiniowałabym drag kinga jako osobę, która - niezależnie od jej identyfikacji płciowej - bawi się na scenie granicami płci i je przekracza. Drag king najczęściej odgrywa postacie męskie - jednak duża część performansów znajduje się też w strefie leżącej między kobiecością a męskością, krążąc wokół płci, która jest niedookreślona lub przechodzi z jednej płci w inną.

Kamp, bardzo widoczny w występach drag queens, jest jednym z ostatnich elementów, które można wskazać w przypadku drag kings. Choć kamp w dużej mierze wiąże się z zabawą, to w występach drag kings zabawa rzadko niesie ze sobą przejawy kampowości. Chcę poruszyć jednak kwestię tego, co w rozdziale pierwszym pozostało nierozstrzygnięte, a mianowicie - czy kamp może 
być polityczny. Według Sontag - nie może (1979: 308), lecz inne badaczki i badacze (Butler 2008; Newton 2012; Meyer 2012; Perkovich 2012) wskazują na subwersywność i polityczność kampu. Po przeprowadzonych badaniach sądzę, że rację ma druga strona. Jeden z przykładów kampu, który opisałam w poprzedniej części artykułu, doskonale wskazuje na fakt, iż połączenie kampu z zaangażowaniem politycznym jest możliwe.

Wszystkie badane znają pojęcie genderbendingu i każda z nich uważa, że w pewnym stopniu przekracza swoją płeć także w życiu prywatnym. Stąd można wysnuć wniosek, że przekraczanie płci ma duży wpływ na chęć występowania jako drag king. Co więcej, wszystkie badane są - lub były zaangażowane w ruchy feministyczne bądź LGBTQ. Mają one wyrobione zdanie na temat działań tychże ruchów, w większości zgadzając się z ich postulatami i kierując często sceniczne działania przeciwko heteronormie.

Analiza wypowiedzi moich badanych przyniosła wyniki podobne do wyników innych badań na temat tego zjawiska w Polsce. Dorota Majka-Rostek wskazywała, iż motywacje drag kingów można podzielić na dwie kategorie: osobiste i posiadające pewne elementy ideowe (2010: 11-12). W motywacjach osobistych badaczka zawarła chęć dobrej zabawy, co ja postanowiłam jednak odróżnić od indywidualnych motywacji. Motywacje osobiste są dosyć szerokim określeniem, do którego należeć może oczywiście także zabawa - jednak ten aspekt na tyle odróżniał się od pozostałych motywacji indywidualnych, że uznałam, iż powinien należeć do osobnej kategorii.

Z moich badań wynika, że nie da się jednoznacznie określić, czym jest występ drag kings. Z wypowiedzi badanych oraz z analizy występów można wysnuć wniosek, iż performansy drag kings są po części wszystkim - można w nich dostrzec zarówno elementy zabawy, jak i kampu oraz zaangażowania politycznego.

Na zabawę zwracają uwagę choćby sposoby, w jaki performerki rozpoczęły swoją przygodę z drag kingowaniem, czy też motywacje, które towarzyszyły im przed pierwszym występem. Elementy kampowe - choć obecne w performansach drag kings - nie są w nich tak dobrze widoczne jak w występach drag queens. Wiele występów balansuje jednak na granicy między kampem a zabawą, co sprawia, że ciężko jest zaklasyfikować je jednoznacznie do którejś z tych kategorii. 
Część motywacji, o których opowiadały badane, dotyczyła zaangażowania politycznego, jednak to interpretacja występów wskazuje na polityczność w większym stopniu niż same wypowiedzi. Tylko jedna badana - DK Gender Genetrix - powiedziała, iż chciałaby, aby jej występy miały wymiar polityczny. Z analizy performansów wyłania się jednak wiele możliwych queerowych i feministycznych interpretacji.

Z wypowiedzi badanych wynika, iż dla nich samych największe znaczenie mają motywacje osobiste. To ta kategoria motywacji najczęściej pojawiała się, gdy performerki mówiły o powodach, dla których występują.

Jak wynika z moich badań, na zjawisko drag kings nie można patrzeć tylko przez pryzmat zabawy lub zaangażowania politycznego. Jest to zjawisko zróżnicowane i w dużej mierze zależne od poszczególnych performerek. Można jednak z pewnością stwierdzić, iż w odróżnieniu od drag queens, drag kings rzeczywiście mają duży potencjał polityczny - który niejednokrotnie wykorzystują. Nie jest to jednak regułą, gdyż performerki nie kierują się wyłącznie aktywizmem, lecz - przede wszystkim - osobistymi potrzebami.

\section{BIBLIOGRAFIA}

Adler, Bartłomiej. 2008. Uważaj! To "jest" kamp. W: (red.) Oczko, Piotr. CAMPania. Zjawisko campu we wspótczesnej kulturze. Warszawa: Wydawnictwo Krytyki Politycznej, s. 20-28.

Berkovitz, Dana i in. 2007. The interaction of drag queens and gay men in public and private spaces. W: „Journal of Homosexuality" 3-4, s. 11-32.

Binnie, Jon. 1997. Coming out of geography: towards a queer epistemology? W: "Environment and Planning D: Society and Space" 15, s. 223-237.

Butler, Judith. 1993. Bodies that matter: on the discursive limits of "sex". New York: Routledge.

---. 2008. Uwikłani w płeć. Warszawa: Wydawnictwo Krytyki Politycznej.

---. 2012. Od „wnętrza” do performatywów ptci. W: (red.) Czapliński, Przemysław, Mizerka, Anna. Kamp. Antologia przekładów. Kraków: Universitas, s. 491-502.

Czapliński, Przemysław. 2012. Kamp - gry antropologiczne. W: (red.) Czapliński, Przemysław, Mizerka, Anna. Kamp. Antologia przekładów. Kraków: Universitas, s. 7-48.

Czapliński, Przemysław, Anna Mizerka. 2012. Mały słownik kampowych kontekstów. W: (red.) Czapliński, Przemysław, Mizerka, Anna. Kamp. Antologia przekładów. Kraków: Universitas, s. 685-698.

Devor, Holly. 1989. Gender blending: confronting the limits of duality. Bloomington: Indiana University Press. 
DiFranco, Dante. 2004. The art of drag kinging: drag'ging out your inner king. Louisville: Wasteland Press.

Ellis, Carolyn i in. 2011. Autoethnography: an overview. "Forum: Qualitative Social Research" 12(1). <http://www.qualitative-research.net/index.php/fqs/article/view/1589>; dostęp: 01.10.2014.

Foley, Douglas, Angela Venezuela. 2009. Etnografia krytyczna. Polityka wspótpracy. W: (red.) Denzin, Norman K., Lincoln, Yvonna S. 2009. Metody badań jakościowych. Tom 1. Warszawa: Wydawnictwo Naukowe PWN, s. 315-339.

Halberstam, Judith. 1998. Female masculinity. Durham, London: Duke University Press.

Hammersley, Martyn, Paul Atkinson. 2000. Metody badań terenowych. Poznań: Wydawnictwo Zysk i S-ka.

Holstein, James A., Jaber F. Gubrium. 2009. Praktyki interpretacyjne a działanie społeczne. W: (red.) Denzin, Norman K., Lincoln, Yvonna S. Metody badań jakościowych. Tom 1. Warszawa: Wydawnictwo Naukowe PWN, s. 677-705.

Kaliściak, Tomasz. 2008. Święty kamp. Psychoanalityczne studium świętego Sebastiana. W: (red.) Oczko, Piotr. CAMPania. Zjawisko campu we wspótczesnej kulturze. Warszawa: Wydawnictwo Krytyki Politycznej, s. 134-142.

Konarzewska, Marta. 2010. Pteć drag kinga. W: (red.) Szkudlarek, Paulina. Przebrani w płeć. Zjawisko drag w kulturze. Poznań: Stowarzyszenie Kobiet Konsola, s. 26-45.

Kulpa, Robert. 2002. Karnawat? Kamp i gender w Drag Queen Show. "Konteksty. Polska Antropologia" 3-4, http://discovery.ucl.ac.uk/3482/1/3482.pdf; dostęp: 21.10.2013.

Łojas, Joanna, Wiktor Dynarski. 2010. Ptciowość (w) drag. Kulturowa tożsamość czy kultura tożsamości? W: (red.) Szkudlarek, Paulina. Przebrani w pteć. Zjawisko drag w kulturze. Poznań: Stowarzyszenie Kobiet Konsola, s. 46-53.

Majka-Rostek, Dorota. 2010. Drag king jako emanacja kultury późnej nowoczesności. W: (red.) Szkudlarek, Paulina. Przebrani w płeć. Zjawisko drag w kulturze. Poznań: Stowarzyszenie Kobiet Konsola, s. 7-16.

Malinowska, Anna. 2008. Camp a sprawa polska, czyli krótka zaduma nad kondycja polskiego kampu. W: (red.) Oczko, Piotr. CAMPania. Zjawisko campu we wspótczesnej kulturze. Warszawa: Wydawnictwo Krytyki Politycznej, s. 150-155.

Marszałek, Dorota. 2010. Zabawa w/z/na gender, genderfuck, euforia gender kontra ptciowy konserwatyzm. Rzecz o występach Drag Queen i Drag King. W: (red.) Szkudlarek, Paulina. Przebrani w płeć. Zjawisko drag w kulturze. Poznań: Stowarzyszenie Kobiet Konsola, s. 63-72.

Meyer, Moe. 2012. Dyskurs kampu. Rewindykacja. W: (red.) Czapliński, Przemysław, Mizerka, Anna. Kamp. Antologia przekładów. Kraków: Universitas, s. 525-550.

Newton, Esther. 2012. Wzorce ról. W: (red.) Czapliński, Przemysław, Mizerka, Anna. Kamp. Antologia przekładów. Kraków: Universitas, s. 469-490.

Perkins, Roberta. 2002. The drag queen scene: transsexuals in Kings Cross. W: (red.) Ekins, Richard, King, David. Blending genders: social aspects of cross-dressing and sex changing. Londyn: Routledge, s. 53-62.

Perkovich, Mike. 2012. Michaśki, kamp, cioty i literatura amerykańska. W: (red.) Czapliński, Przemysław, Mizerka, Anna. Kamp. Antologia przekładów. Kraków: Universitas, s. 144-167. 
Ross, Andrew. 2012. Kamp: sposoby użycia. W: (red.) Czapliński, Przemysław, Mizerka, Anna. Kamp. Antologia przekładów. Kraków: Universitas, s. 328-369.

Rupp, Leila J. i in. 2010. Drag queens and drag kings: the difference gender makes. W: "Sexualities" 13 , s. $275-294$.

Schacht, Steven P., Lisa Underwood (red.). 2004. The drag queen anthology: the absolutely fabulous but flawlessly customary world of female impersonators. Binghamton: The Haworth Press.

Serafin, Andrzej. 2008. Krótki kurs historii campu. W: (red.) Oczko, Piotr. CAMPania. Zjawisko campu we wspótczesnej kulturze. Warszawa: Wydawnictwo Krytyki Politycznej, s. 8-19.

Sontag, Susan. 1979. Notatki o kampie. W: „Literatura na świecie” 9, s. 306-323.

Świrek, Anna. 2010. Performatywne aspekty queer - krótka historia rozwoju kultury drag kings na scenie zagranicznej i polskiej. W: (red.) Abramowicz, Marta, Biedroń, Robert Kochanowski, Jacek. Queer studies. Podręcznik kursu. Warszawa: Kampania Przeciw Homofobii, s. 147-158.

Szkudlarek, Paulina (red.). 2010. Przebrani w pteć. Zjawisko drag w kulturze. Poznań: Stowarzyszenie Kobiet Konsola.

Taylor, Verta, Leila J. Rupp. 2004. Chicks with dicks, men in dresses. What it means to be a drag queen. W: "Journal of Homosexuality” 3-4, s. 113-133.

Troka, Donna Jean i in. 2002. The drag king anthology. Nowy Jork: Haworth Press.

Zakrzewska, Joanna. 2005. Kamp - kłamstwo, które mówi prawdę? Dandyzm XX wieku? W: (red.) Slany, Krystyna, Kowalska, Beata, Śmietana, Marcin. Homoseksualizm. Perspektywa interdyscyplinarna. Kraków: Zakład wydawniczy NOMOS, s. 235-246. 